\title{
Effect of Non-thermal Plasma on Physicochemical Properties of Nam Dok Mai Mango
}

\author{
Khanh Phan Thi Kim ${ }^{1,2}$, Huan Phan Tai ${ }^{3}$, Kasemsak Uthaichana ${ }^{4}$, Yuthana Phimolsiripol ${ }^{2,5^{*}}$ \\ ${ }^{1}$ Graduate School, Chiang Mai University, Chiang Mai, Thailand \\ ${ }^{2}$ Faculty of Agro-Industry, Chiang Mai University, Chiang Mai, Thailand \\ E-mail:ptkkhanh@hcmuaf.edu.vn \\ ${ }^{3}$ Faculty of Food Science and Technology, Nong Lam University, Ho Chi Minh City, Vietnam \\ E-mail: pthuan@hcmuaf.edu.vn \\ ${ }^{4}$ Department of Electrical Engineering, Faculty of Engineering, Chiang Mai University, Chiang Mai, Thailand \\ E-mail: kasemsak.u@cmu.ac.th \\ 5* Food Innovation and Packaging Center, Chiang Mai University, Chiang Mai, Thailand \\ E-mail: yuthana.p@cmu.ac.th
}

\begin{abstract}
Mango is considered as a popular and economically important tropical fruit around the world because of its attractive color, favorable flavor, and high nutritional quality. Nowadays, more consumers consciously desire not only fresh and nutritious but also safe fruits with low or free of microorganisms and chemical contamination. Non-thermal plasma (NTP) is one of the emerging technologies that could potentially decontaminate the fresh food and food processing surfaces. Recently, NTP emerges as a new sanitizing method in the agro-industrial application, where the qualitative characteristics of the treated product could probably be modified by the reactive species as well as the residues of oxidation processes. This study evaluates the changes of physicochemical indexes of Nam Dok Mai mango treated with several NTP conditions. The NTP process was discharged in $0.05 \%$ sodium bicarbonate solution under different voltage levels $(800-1500 \mathrm{~V})$ and various treatment durations $(2-10 \mathrm{~min})$. It was found that there were significant decreases $(\mathbf{p}<0.05)$ in titratable acidity and total phenolic content of NTP treated mango, while the total soluble solid showed a significant increase $(\mathbf{p}<\mathbf{0 . 0 5})$. The color and texture parameters of this fruit with NTP treatments were not significantly different (p>0.05). The results demonstrated that NTP had slight effect on the physicochemical properties of mango. Future work is required to investigate more comprehensive effect of NTP on the pesticides residues in the mango.
\end{abstract}

Keywords — non-thermal plasma; mango; color; texture; phenolic compound.

\section{INTRODUCTION}

Nowadays, health concerns on consumed fruits and vegetables prompt the need of safe, fresh and high nutritious products undergoing minimal processing with low or free of microbes and chemical contamination. Accordingly, novel non-thermal processes for decontamination chemical residues and microorganisms together with maintaining nutritional and sensory qualities of fruits are required [1]. Mango (Mangifera indica L.) is considered as a popular and economically important tropical fruit around the world because of its attractive color, favorable flavor, and high nutritional qualities [2]. Thailand is in the fourth rank of producing mango in the world (1.8 million tons production), with a $27 \%$ share of world market and an emphasis in Japan and Europe [3]. The Nam Dok Mai mango is one of the most famous cultivars for consumption at the ripe stage in Thailand [4]. However, various microorganisms on this fruit lead to quality deterioration, lower market value, and sometimes the rejections of the fruit shipment at the destination countries.

Conventional postharvest washing treatments are not highly effective for eliminating pesticide residues as well as against the growth of mold and pathogens [1]. Chemical sanitizing methods which are commonly used in the food industry now, have increased public health concerns about the risk of carcinogenic by-products formation [5-7]. Other thermal treatments can ensure a safe toxic level for food, but they also have undesirable effects on the flavor, color and texture of products [8]. Non-thermal plasma (NTP) is one of 
the emerging novel technologies that could potentially decontaminate fresh food and food processing surfaces.

Plasma is considered to be the forth state of matter [9-11] and defined as a mixture of partially ionized gas [12-14] containing reactive species like electrons, charged ions, free radicals, gas atoms and photons [14-16]. NTPs are characterized by an electron temperature and do not present a local thermodynamic equilibrium, thus operating temperature of NTP is around $30-60{ }^{\circ} \mathrm{C}$ which is preferred by the food industry due to the low energy required for plasma generation [17]. NTP using a dielectric barrier discharge to degrade pesticide residues on strawberries had been successfully investigated [18]. By applying NTP, harmful bacteria and toxins in fruits, vegetables, and meat products can be eliminated effectively while the fresh taste, aroma, texture, wholesomeness, and nutritional content of them are still preserved [14, 19].

Nevertheless, there are still limited studies conducting on physicochemical or nutritional qualities of fresh fruits and vegetables in general, and those of mangoes in particular after plasma treatment. The presence of reactive species as well as the residues of oxidation processes could probably promote the modification of physicochemical and sensory characteristics of the plasma treated products [20]. The objective of this study was to quantify effects of different operating NTP conditions on color, texture, total soluble solid (TSS), titratable acidity (TA) and total phenolic content (TPC) of Nam Dok Mai mango.

\section{MATERIALS AND METHODS}

\section{A. Materials}

A number of Nam Dok Mai mango fruits were purchased from a company exporting mango. Fruits were packed in carton boxes, transported to the laboratory and stored in a closed refrigerated chamber at $4-5{ }^{\circ} \mathrm{C}$ until use (maximum 3 days of storage). Mangoes which had uniform size and appearance without mechanical injury were selected for the experiments. All chemicals used in this study were of analytical grade and were purchased from Sigma- Aldrich (St Louis, MO, USA) and ACI Labscan (Rd Pathumwan, Bangkok, Thailand).

\section{B. Plasma treatment of mango fruit}

In this study, the non-thermal plasma system was developed from the method described by Deng et al. [21]. Four major parts including: (1) Non-thermal plasma discharge bath, (2) high-voltage power supply, (3) electrical parameter measurement and (4) control devices. Sodium bicarbonate $\left(\mathrm{NaHCO}_{3}\right)$ solution $(0.05 \%)$ was prepared and filled as solution plasma for increasing electrical conductivity of solution $(550 \mu \mathrm{S} / \mathrm{cm})$. The high conductivity of solution is required for the discharge generation in liquid [22]. Plasma was generated in the solution by applying 426 ns wide of pulse and $50 \mathrm{kHz}$ electric field with different voltage levels through the electrode. The plasma source utilized was a power systems DC generator (DCG-100E, ENI Power Systems). Temperature of plasma solution before and after plasma treatment was ranged from 28 to $45{ }^{\circ} \mathrm{C}$. Increase of temperature was observed by either higher applied voltage or longer treatment duration.
Mango fruits were placed directly in the NTP bath (3 fruits per $3000 \mathrm{~mL}$ solution for each treatment), then different levels of high-voltage power (ranged from 800 to $1500 \mathrm{~V}$ ) were supplied between 2 and $10 \mathrm{~min}$ as shown in Table 1. After NTP treatments, the mango samples were recovered and taken for physicochemical properties measurements. The control sample was mango fruit without any NTP treatment.

TABLE I

DESCRIPTION OF NTP TREATMENTS

\begin{tabular}{|c|c|c|}
\hline Simple description & Voltage level (V) & $\begin{array}{c}\text { Treatment time } \\
(\mathbf{m i n})\end{array}$ \\
\hline D800_2 min & 800 & 2 \\
\hline D1000_2 min & 1000 & 2 \\
\hline D1200_2 min & 1200 & 2 \\
\hline D1500_2 min & 1500 & 2 \\
\hline D1200_4 min & 1200 & 4 \\
\hline D1200_6 min & 1200 & 6 \\
\hline D1200_10 min & 1200 & 10 \\
\hline
\end{tabular}

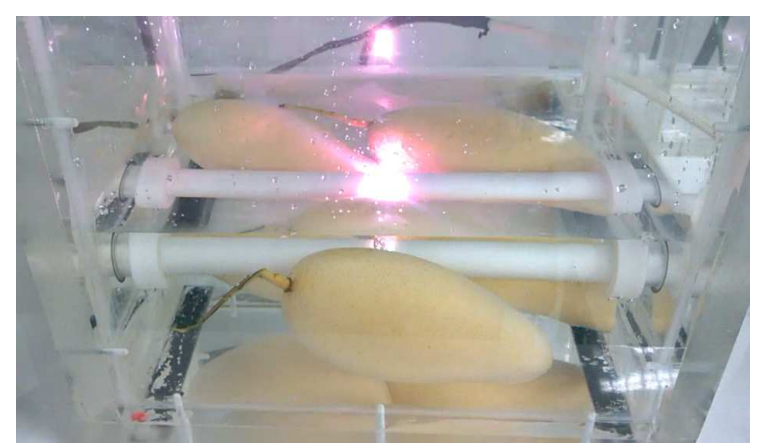

Fig. 1 Mango treated NTP discharged in $\mathrm{NaHCO}_{3}$ solution

\section{Color measurement}

The CIE ( $\mathrm{L}^{*}, \mathrm{a}^{*}$ and $\mathrm{b}^{*}$ ) of skin color of mango was determined at selected points on both sides of the fruit control and after the plasma treatments using a colorimeter (CR-410, Konica-Minolta, Japan) with ten measurements per fruit. The overall mango color change was indicated by $\Delta \mathrm{E}^{*}$ which calculated according to the following equation:

$$
\Delta \mathrm{E}^{*}=\sqrt{\left(L_{c}^{*}-L_{t}^{*}\right)^{2}+\left(a_{c}^{*}-a_{t}^{*}\right)^{2}+\left(b_{t}^{*}-b_{t}^{*}\right)^{2}}
$$

where $\mathrm{L}^{*}, \mathrm{a}_{\mathrm{c}}$ and $\mathrm{b}_{\mathrm{c}}$ are the color values of control sample (mango fruits without any plasma treatment), and $\mathrm{L}^{*}$, $a^{*}$ and $b^{*}$ are the color values of fruits with plasma treatments $[23,24]$.

\section{Texture analysis}

Mango samples were equilibrated to room temperature $\left(28{ }^{\circ} \mathrm{C}\right)$ and cut into uniform cubes $\left(1.5 \times 1.5 \times 1.5 \mathrm{~cm}^{3}\right)$ before taking textural analysis. Texture of mango was evaluated by applying texture profile analysis (TPA) with a texture analyzer (TA-XTplus, Stable Micro Systems, USA) following the method of Banjongsinsiri et al. [25]. A cylindrical probe $(50 \mathrm{~mm}$ diameter) was chosen to perform TPA tests. Samples were compressed in two consecutive cycles to get $25 \%$ deformation from the initial sample height of $1.5 \mathrm{~cm}$, at a speed of $2 \mathrm{~mm} \mathrm{~s}^{-1}$. The textural parameters determined were hardness, cohesiveness, springiness, gumminess and chewiness. 
The first maximum force which is necessary to compress the mango cube sample is defined as the hardness and measured in newtons $(\mathrm{N})$. The ratio of the area of work during the second compression divided by the area of work during the first compression is the cohesiveness. Springiness is the distance $(\mathrm{mm})$ at which the sample was compressed by the peak force of second compression. The product of hardness and cohesive is the gumminess $(\mathrm{N})$ while chewiness $(\mathrm{N} \times \mathrm{mm})$ is calculated from gumminess and springiness. For each treatment, at least fifteen samples were analyzed.

\section{E. Titratable acidity and total soluble solids measurement}

Titratable acidity (TA) was determined by titration with $\mathrm{NaOH} 0.1 \mathrm{~N}$ and two to three drops of $0.1 \%(\mathrm{w} / \mathrm{v})$ phenolphthalein as an indicator [26]. The results were expressed as percent of citric acid (\%).

Total soluble solids (TSS), expressed as ${ }^{0}$ Brix, were measured with a refractometer (Atago, Tokyo, Japan) at $25 \pm$ $1{ }^{\circ} \mathrm{C}[23]$.

\section{F. Total phenolic content (TPC) measurement}

Blended $2.5 \mathrm{~g}$ mango flesh were added into $20 \mathrm{~mL}$ of ethanol-acetone solution (ratio 7:3) and kept in ultrasonic bath for $1 \mathrm{~h}$ to extract followed by the centrifugation process at $10,000 \mathrm{rpm}$ in $15 \mathrm{~min}$. Supernatant was collected and analyzed of total phenolic content. Three replications were applied for each treatment [23]. Total phenolic content were determined following Siddiq et al. [23]. Taking $0.5 \mathrm{~mL}$ of standard or extracted sample and $0.5 \mathrm{~mL}$ of Foline-Ciocalteu reagent (diluted 10 times with distilled water) into small test tubes, the mixture was shaken well for $15 \mathrm{~s}$. After $3 \mathrm{~min}$, adding $1 \mathrm{~mL}$ of saturated sodium carbonate (about $75 \mathrm{~g} / \mathrm{L}$ ) and $1 \mathrm{~mL}$ of distilled water into these tubes. The mixture was incubated in the dark area for $2 \mathrm{~h}$ before its absorption was measured at $725 \mathrm{~nm}$ against de-ionized water by spectrophotometer (PerkinElmer Lambda 25, UV/Vis Spectrophotometer). The data were expressed in $\mathrm{mg}$ gallic acid equivalents (GAE)/ $100 \mathrm{~g}$ fresh weight (FW).

\section{G. Statistical analysis}

Completely randomized design (CRD) with three replications per treatment was done for the experiment. Data analysis was performed using SPSS statistical package 16.0 (SPSS Inc., USA). Mango quality attributes including color, texture, TSS, TA and TPC of the control and plasma treated samples were tested for significance $(\mathrm{p} \leq 0.05)$ by one-way analysis of variance (ANOVA) and Duncan's post hoc test.

\section{RESULTS AND DISCUSSION}

\section{A. Color of mango}

Color is one of the most important quality attributes for the consumer's acceptability of fresh fruits [24]. The values of color parameters of mango treated plasma and the control were shown in Table 2 . There was not significantly different ( $p>0.05)$ between $L^{*}, a^{*}$ and $b^{*}$ values of control, D800_2 min, D1000_2 min, D1200_2 $\min$ and D1200_4 min. However, when compared with the control, the $\mathrm{L}^{*}$ and $\mathrm{b}^{*}$ values of D1200_10 min slightly increased. D1200_6 min also had the higher $b^{*}$ value and $a^{*}$ value than those of the control. Overall mango color change $\left(\Delta \mathrm{E}^{*}\right)$ was not significantly different $(\mathrm{p}>0.05)$ among treatments. Alterations in color parameters of corn salad leaves [27] and bell peppers [28] which are treated NTP have been observed. However, color of strawberries and tomatoes applied NTP shows insignificant changes [18, 29].

\section{B. Mango texture}

Texture parameters of the control and samples treated plasma were not significantly different $(p>0.05)$ (Table 3). There is also an insignificant difference in the firmness values of treated cold plasma tomatoes when comparing with the control [5]. Ma et al. [24, 30] found similarly that plasma activated water (PAW) could maintain the firmness of strawberries and bayberries. It might be said that the nonthermal plasma treatments would not affect a lot on texture quality of mango fruit.

\section{TSS and TA values of fruit}

The results of TSS and TA of the control and plasma treatments were displayed in Fig. 2. The TSS values ranged from 9.5 to $13{ }^{\circ}$ Brix with the highest one found in D1000_2 min. All plasma treatments had significantly higher TSS content $(p \leq 0.05)$ than the control. As the main substrates of respiratory metabolism, sugars and acids are consumed, causing corresponding changes in TSS of fruits. Higher contents of TSS in plasma treated mangoes may be due to the effect of NTP treatments on the respiratory rate of mango which consequently increased the consumption of sugars and acids of this fruit [30].

TABLE II

Color Parameters Of Control AND MANGo Treated Plasma

\begin{tabular}{|l|l|l|l|l|}
\hline Test ID & $\mathbf{L}^{*}$ & $\mathbf{a}^{*}$ & $\mathbf{b}^{*}$ & $\Delta \mathbf{E}^{*}$ \\
\hline Control & $71.97^{\mathrm{a}} \pm 1.61$ & $-4.14^{\mathrm{a}} \pm 1.05$ & $33.33^{\mathrm{ab}} \pm 2.69$ & \\
\hline D800_2 min & $72.21^{\mathrm{ab}} \pm 1.52$ & $-4.38^{\mathrm{a}} \pm 0.76$ & $32.72^{\mathrm{a}} \pm 1.95$ & $3.24^{\mathrm{a}} \pm 1.76$ \\
\hline D1000_2 min & $72.01^{\mathrm{a}} \pm 1.38$ & $-4.55^{\mathrm{a}} \pm 0.47$ & $34.50^{\mathrm{bcd}} \pm 1.64$ & $4.22^{\mathrm{a}} \pm 1.72$ \\
\hline D1200_2 min & $72.23^{\mathrm{ab}} \pm 1.42$ & $-4.30^{\mathrm{a}} \pm 0.91$ & $33.98^{\mathrm{abc}} \pm 1.25$ & $3.32^{\mathrm{a}} \pm 1.36$ \\
\hline D1500_2 min & $71.78^{\mathrm{a}} \pm 1.2$ & $-4.55^{\mathrm{a}} \pm 0.47$ & $35.52^{\mathrm{d}} \pm 1.32$ & $4.08^{\mathrm{a}} \pm 1.41$ \\
\hline D1200_4 min & $71.62^{\mathrm{a}} \pm 1.26$ & $-4.07^{\mathrm{a}} \pm 1.16$ & $33.65^{\mathrm{ab}} \pm 0.78$ & $3.31^{\mathrm{a}} \pm 1.44$ \\
\hline D1200_6 min & $72.50^{\mathrm{ab}} \pm 1.55$ & $-3.27^{\mathrm{b}} \pm 0.88$ & $35.36^{\mathrm{d}} \pm 2.25$ & $3.92^{\mathrm{a}} \pm 1.39$ \\
\hline D1200_10 min & $73.21^{\mathrm{b}} \pm 1.11$ & $-3.92^{\mathrm{a}} \pm 0.95$ & $35.15^{\mathrm{cd}} \pm 1.08$ & $4.14^{\mathrm{a}} \pm 1.67$ \\
\hline
\end{tabular}


TABLE III

Texture Profile Analysis Of The Control And Mango Treated Plasma

\begin{tabular}{|c|c|c|c|c|c|}
\hline Test ID & $\begin{array}{c}\text { Hardness }^{\text {ns }} \\
(\mathbf{N})\end{array}$ & $\begin{array}{c}\text { Cohesiveness }^{\text {ns }} \\
(\text { unitless })\end{array}$ & $\begin{array}{c}\text { Springiness }^{\text {ns }} \\
(\mathbf{m m})\end{array}$ & $\begin{array}{c}\text { Gumminess }^{\text {ns }} \\
(\mathbf{N})\end{array}$ & $\begin{array}{c}\text { Chewinesss }^{\text {ns }} \\
(\mathbf{N} \text {.mm) }\end{array}$ \\
\hline Control & $2.39 \pm 0.82$ & $0.21 \pm 0.02$ & $0.54 \pm 0.05$ & $0.43 \pm 0.1$ & $0.23 \pm 0.06$ \\
\hline D800_2 min & $2.20 \pm 0.8$ & $0.22 \pm 0.02$ & $0.52 \pm 0.09$ & $0.43 \pm 0.15$ & $0.23 \pm 0.09$ \\
\hline D1000_2 min & $2.15 \pm 0.94$ & $0.21 \pm 0.03$ & $0.51 \pm 0.07$ & $0.41 \pm 0.08$ & $0.24 \pm 0.03$ \\
\hline D1200_2 min & $2.39 \pm 0.68$ & $0.23 \pm 0.02$ & $0.51 \pm 0.08$ & $0.45 \pm 0.1$ & $0.25 \pm 0.07$ \\
\hline D1500_2 min & $2.22 \pm 0.87$ & $0.21 \pm 0.02$ & $0.52 \pm 0.07$ & $0.42 \pm 0.07$ & $0.26 \pm 0.09$ \\
\hline D1200_4 min & $2.19 \pm 0.8$ & $0.22 \pm 0.01$ & $0.51 \pm 0.08$ & $0.44 \pm 0.12$ & $0.24 \pm 0.08$ \\
\hline D1200_6 min & $2.38 \pm 0.61$ & $0.21 \pm 0.04$ & $0.56 \pm 0.05$ & $0.42 \pm 0.08$ & $0.25 \pm 0.04$ \\
\hline D1200_10 min & $2.12 \pm 0.6$ & $0.20 \pm 0.02$ & $0.54 \pm 0.08$ & $0.44 \pm 0.07$ & $0.24 \pm 0.07$ \\
\hline
\end{tabular}

${ }^{\mathrm{ns}}$ indicates no significantly different $(\mathrm{p}>0.05)$

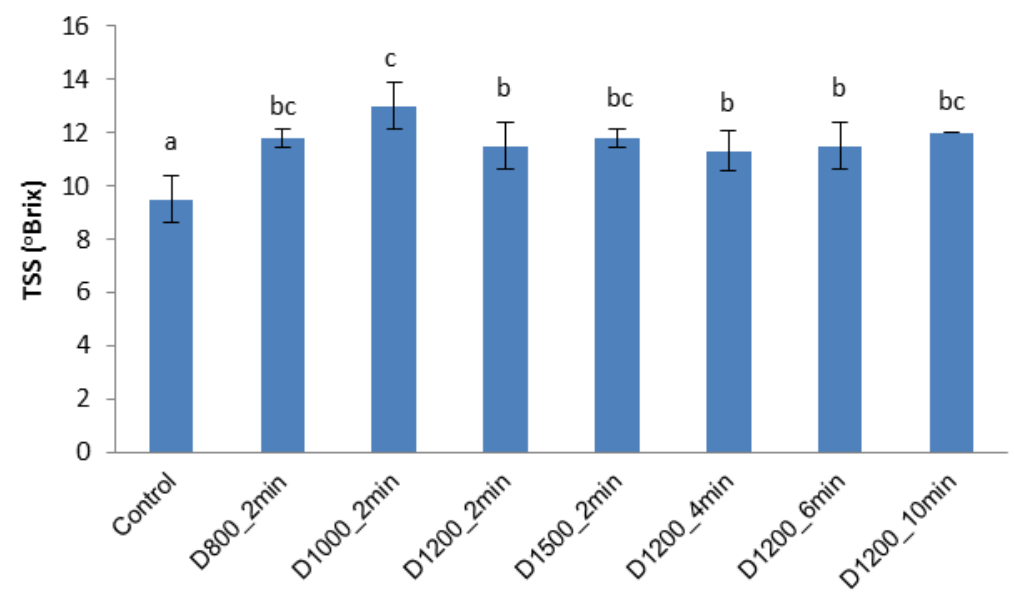

Fig. 2 Total soluble solid (TSS) of mango flesh of control and NTP treatments Mean values with different letters are significantly different $(\mathrm{p} \leq 0.05)$

TA is an essential parameter used to evaluate storage characteristics of fruits. High decrease in value of TA reflects the senescence of fruits [2]. In this study, TA percentage of mangoes decreased significantly $(p \leq 0.05)$ with all NTP treatments when comparing with this of the controlled sample (Fig. 3). The maximum TA reduction was observed in D1500_2min. Titratable acidity decrease with advancing fruit ripening [2] and NTP plasma with temperature between 28 and $45{ }^{\circ} \mathrm{C}$ may cause some effects supporting the faster maturity of mango. Moreover, the reaction of fruit's cells with reactive oxygen species generated by plasma chemistry could be used to explain the loss of fruit quality during processing [31].

\section{Total phenolic content}

Phenolic contents in mangoes have been reported to vary from 15.3 to $266 \mathrm{mg} \mathrm{GAE} / 100 \mathrm{~g} \mathrm{FW}[32,33]$. The higher phenolic contents can potentially contribute to improved antioxidant activity [34]. For this research, the phenolic content of the control was $144.91 \mathrm{mg} \mathrm{GAE} / 100 \mathrm{~g} \mathrm{FW}$ while treated NTP samples had significantly lower contents ( $\mathrm{p} \leq 0.05$ ) from 84.68 to $138.54 \mathrm{mg} \mathrm{GAE} / 100 \mathrm{~g} \mathrm{FW}$ (Fig. 4). Among various treatment conditions, the lowest phenolic content was observed in D1200_2 min sample. Scavenging free radicals is known as the ability of phenolic compound leading to cleavage of the central heterocyclic in polyphenolic skeleton as well as oligomerization subsequently [35]. Grzegorzewski et al. [36] found that the degradation of phenolic compounds in lamb's lettuce was not made by photo- or thermodesorption processes at the surface but by the combined interaction of various reactive species of plasma. The interactions with charged ions and reactive species like $\bullet \mathrm{OH}, \mathrm{O}$ and $\mathrm{O}_{2}$ may cause an erosion of epidermal tissue layers of this vegetable from that flavonoids and other compounds stored in the central vacuoles of guard cells as well as epidermal cells are released and degraded [36].

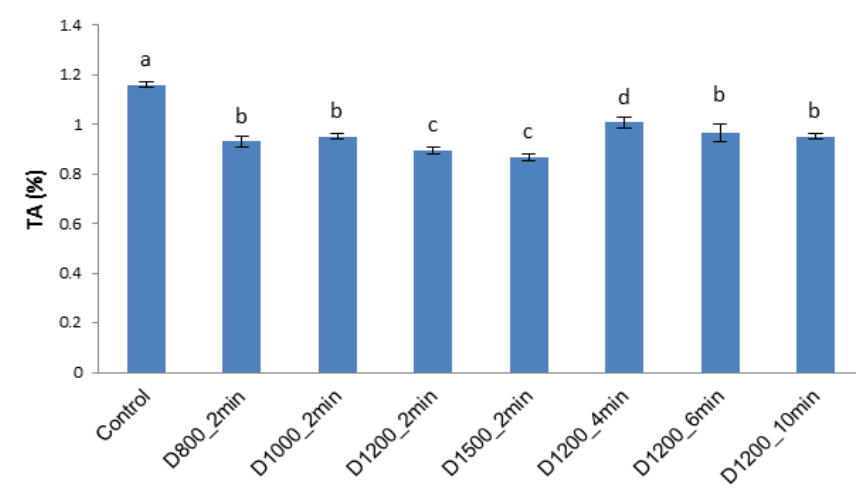

Fig 3 Titratable acidity (TA) of mango flesh of control and NTP treatments Mean values with different letters are significantly different $(\mathrm{p} \leq 0.05)$ 


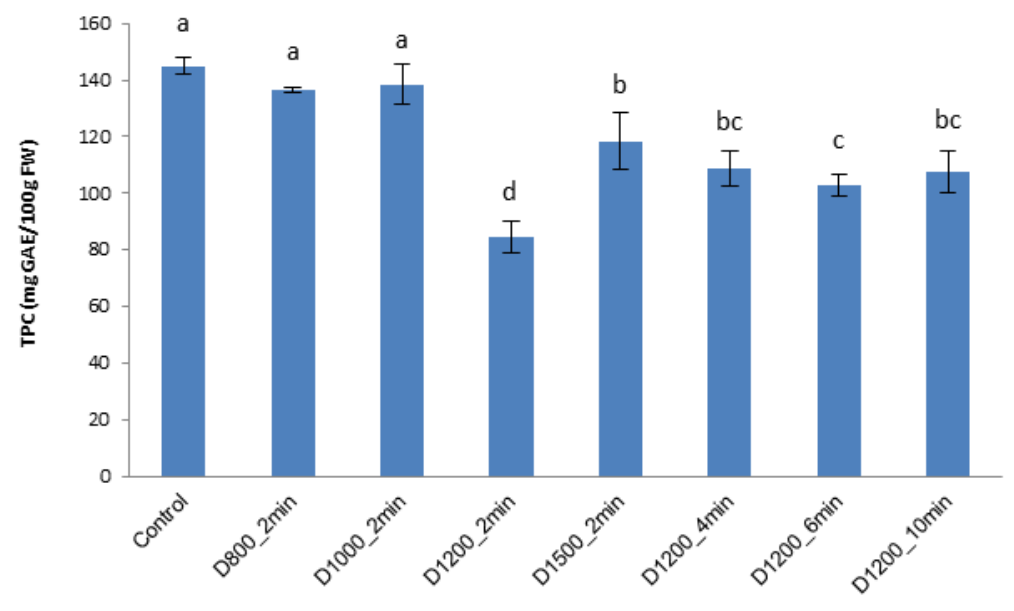

Fig. 4 Total phenolic content (TPC) of flesh of control and NTP treatments Mean values with different letters are significantly different $(\mathrm{p} \leq 0.05)$

\section{CONCLUSIONS}

NTP could cause some significant changes on the physicochemical indexes of mango including TSS, TA and TPC. There were also some minor alterations in color parameters but no significantly impact on mango texture when compared to the control. Although further investigations should be carried out to elucidate the chemical kinetics mechanisms of these effects, NTP still can be a new promising as an alternative sanitizing method to decontamination chemicals and pathogens from various types of fresh fruits and vegetables due to many advantages of it including high efficiency, low temperature, independence of chemicals together with openly and continuously operation.

\section{ACKNOWLEDGMENT}

Authors would like to thank for financial support from ASEAN+3 Cross Border Research, International College, Chiang Mai University, National Research Council of Thailand (NRCT) and Agricultural Research Development Agency (ARDA).

\section{REFERENCES}

[1] A. Lacombe, B. A. Niemira, J. B. Gurtler, X. Fan, J. Sites, G. Boyd, H. Chen, "Atmospheric cold plasma inactivation of aerobic microorganisms on blueberries and effects on quality attributes," Food Microbiology, vol. 46, pp. 479-484, 2015.

[2] G. Khaliq, M. T. Muda Mohamed, A. Ali, P. Ding, H. M. Ghazali, "Effect of gum arabic coating combined with calcium chloride on physico-chemical and qualitative properties of mango (Mangifera indica L.) fruit during low temperature storage," Scientia Horticulturae, vol. 190, pp. 187-194, 2015.

[3] L. Wongkaew, S. Likittrakoolrung, "Pestilential diseases in 'Maha Chanok' mango," Kasikorn, vol. 82(6), pp. 43-47, 2009.

[4] (2008) Thai Mango-Ma-Muang. Available: http://www.simplythai.com/ThaiMarket_Fruit_Mango

[5] N. N. Misra, K. M. Keener, P. Bourke, J. P. Mosnier, P. J. Cullen, "In-package atmospheric pressure cold plasma treatment of cherry tomatoes," Journal of Bioscience and Bioengineering, vol. 118, pp. $177-182,2014$
[6] C. I. Wei, D. L. Cook, J. R. Kirk, "Use of chlorine compounds in the food industry," Food Technologies, vol. 39, pp. 107-115, 1985.

[7] B. Ramos, F. A. Miller, T. R. S. Brandão, P. Teixeira, C. L. M. Silva, "Fresh fruits and vegetables-An overview on applied methodologies to improve its quality and safety," Innovative Food Science and Emerging Technologies, vol. 20, pp. 1-15, 2013.

[8] B. Surowsky, A. Frohling, N. Gottschalk, O. Schluter, D. Knorr, "Impact of cold plasma on Citrobacter freundii in apple juice: inactivation kinetics and mechanisms," International Journal Food Microbiology, vol. 174, pp. 63-71, 2014.

[9] C. Tendero, C. Tixier, P. Tristant, J. Desmaison, P. Leprince, "Atmospheric pressure plasmas: A review," Spectrochimica Acta Part B: Atomic Spectroscopy, vol. 61, pp. 2-30, 2006.

[10] B. Surowsky, A. Fischer, O. Schlueter, D. Knorr, "Cold plasma effects on enzyme activity in a model food system," Innovative Food Science and Emerging Technologies, vol.19, pp. 146-152, 2013.

[11] A. Mai-Prochnow, A. B. Murphy, K. M. McLean, M. G. Kong, K. K. Ostrikov, "Atmospheric pressure plasmas: infection control and bacterial responses," International Journal of Antimicrobial Agents, vol. 43, pp. 508-517, 2014.

[12] B. A. Niemira, "Cold plasma decontamination of foods," Annual Review of Food Science and Technology, vol. 3, pp. 125-142, 2012.

[13] Y. H. Ryu, Y. H. Kim, J. Y. Lee, G. B. Shim, H. S. Uhm, G. Park, E. $\mathrm{H}$. Choi, "Effects of background fluid on the efficiency of inactivating yeast with non-thermal atmospheric pressure plasma," PloS One, vol. 8, e66231, Jun. 2013.

[14] S. K. Pankaj, C. Bueno-Ferrer, N. N. Misra, V. Milosavljević, C. P. O'Donnell, P. Bourke, K. M. Keener, P. J. Cullen, "Applications of cold plasma technology in food packaging," Trends in Food Science and Technology, vol. 35, pp. 5-17, 2014.

[15] A. Fernandez, N. Shearer, D. R. Wilson, A. Thompson, "Effect of microbial loading on the efficiency of cold atmospheric gas plasma inactivation of Salmonella enterica serovar Typhimurium," International Journal of Food Microbiology, vol. 152, pp. 175-180, 2012.

[16] M. Stoica, L. Mihalcea, D. Borda, P. Alexe, "Nonthermal novel food processing technologies_An overview," Journal of Agroalimentary Processes and Technologies, vol. 19 (20), pp. 212-217, 2013.

[17] N. N. Misra, B. K. Tiwari, K. S. M. S. Raghavarao, P. J. Cullen, "Nonthermal plasma inactivation of food-borne pathogens," Food Engineering Reviews, vol. 3, pp. 159-170, 2011.

[18] N. N. Misra, S. K. Pankaj, T. Walsh, F. O'Regan, P. Bourke, P. J. Cullen, "In-package nonthermal plasma degradation of pesticides on fresh produce," Journal of Hazardous Materials, vol. 271, pp. 33-40, 2014.

[19] M. Baier, J. Foerster, U. Schnabel, D. Knorr, J. Ehlbeck, W. B. Herppich, O. Schlüter, "Direct non-thermal plasma treatment for the sanitation of fresh corn salad leaves: Evaluation of physical and physiological effects and antimicrobial efficacy," Postharvest Biology and Technology, vol. 84, pp. 81-87, 2013. 
[20] F. Pasquali, A. C. Stratakos, A. Koidis, A. Berardinelli, C. Cevoli, L. Ragni, R. Mancusi, G. Manfreda, M. Trevisani, "Atmospheric cold plasma process for vegetable leaf decontamination: A feasibility study on radicchio (red chicory, Cichorium intybus L.)," Food Control, vol. 60, pp. 552-559, 2016

[21] S. Deng, R. Ruan, C. K. Mok, G. Huang, X. Lin, P. Chen, "Inactivation of Escherichia coli on almonds using nonthermal plasma," Journal of Food Science, vol. 72, pp. M62-66, 2007.

[22] I. Z. Kozáková, "Electric Discharges in Water Solutions," Habilitation thesis, Faculty of Chemistry, Brno University of Technology, Czech Republic, 2011.

[23] M. Siddiq, D. S. Sogi, K. D. Dolan, "Antioxidant properties, total phenolics, and quality of fresh-cut 'Tommy Atkins' mangoes as affected by different pre-treatments," LWT - Food Science and Technology, vol. 53, pp. 156-162, 2013.

[24] R. Ma, G. Wang, Y. Tian, K. Wang, J. Zhang, J. Fang, "Non-thermal plasma-activated water inactivation of food-borne pathogen on fresh produce," Journal of Hazardous Materials, vol. 300, pp. 643-651, 2015.

[25] P. Banjongsinsiri, S. Kenney, L. Wicker, "Texture and distribution of pectic substances of mango as affected by infusion of pectinmethylesterase and calcium," Journal of the Science of Food and Agriculture, vol. 84, pp. 1493-1499, 2004.

[26] AOAC, "Official Methods of Analysis of the Association of Official Analytical Chemists," Washington, DC, 2000.

[27] M. Baier, M. Görgen, J. Ehlbeck, D. Knorr, W.B. Herppich, O. Schlüter, "Non-thermal atmospheric pressure plasma: Screening for gentle process conditions and antibacterial efficiency on perishable fresh produce," Innovative Food Science and Emerging Technologies, vol. 22, pp. 147-157, 2014.

[28] M. Vleugels, G. Shama, X. T. Deng, E. Greenacre, T. Brocklehurst, M. G. Kong, "Atmospheric plasma inactivation of biofilm-forming bacteria for food safety control," IEEE Transactions on Plasma Science, vol. 33, pp. 824-828, 2005.
[29] D. Bermúdez-Aguirre, E. Wemlinger, P. Pedrow, G. BarbosaCánovas, M. Garcia-Perez, "Effect of atmospheric pressure cold plasma (APCP) on the inactivation of Escherichia coli in fresh produce," Food Control, vol. 34, pp. 149-157, 2013.

[30] R. Ma, S. Yu, Y. Tian, K. Wang, C. Sun, X. Li, J. Zhang, K. Chen, J. Fang, "Effect of non-thermal plasma-activated water on fruit decay and quality in postharvest Chinese bayberries," Food and Bioprocess Technology, vol. 9, pp. 1825-1834, 2016.

[31] N. N. Misra, S. K. Pankaj, J. M. Frias, K. M. Keener, P. J. Cullen, "The effects of nonthermal plasma on chemical quality of strawberries," Postharvest Biology and Technology, vol. 110, pp. 197-202, 2015.

[32] X. Wu, G. R. Beecher, J. M. Holden, D. B. Haytowitz, S. E. Gebhardt, R. L. Prior, 2004, "Lipophilic and hydrophilic antioxidant capacities of common food in the United States," Journal of Agricultural and Food Chemistry, vol. 52, pp. 4026-4037, 2004.

[33] G. D. Noratto, M. C. Bertoldi, K. Krenek, S. T. Talcott, P. C Stringheta, S. U. Mertens-Talcott, "Anticarcinogenic effects of polyphenolics from mango (Mangifera indica) varieties", Journal of Agricultural and Food Chemistry, vol. 58, pp. 4104-4112, 2010.

[34] G. A. González-Aguilar, M. A. Villegas-Ochoa, M. A. MartínezTéllez, A. A. Gardea, J. F. Ayala-Zavala, "Improving antioxidant capacity of fresh-cut mangoes treated with UV-C, Journal of Food Science, vol. 72, pp. S197-S202, 2007.

[35] I. E. Garofulić, A. R. Jambrak, S. Milošević, V. Dragović-Uzelac, Z. Zorić, Z. Herceg, "The effect of gas phase plasma treatment on the anthocyanin and phenolic acid content of sour cherry Marasca (Prunus cerasus var. Marasca) juice," LWT - Food Science and Technology, vol. 62, pp. 894-900, 2015.

[36] F. Grzegorzewski, J. Ehlbeck, O. Schlüter, L. W. Kroh, S. Rohn, "Treating lamb's lettuce with a cold plasma - Influence of atmospheric pressure Ar plasma immanent species on the phenolic profile of Valerianella locusta," LWT - Food Science and Technology, vol. 44, pp. 2285-2289, 2011. 